\title{
South African Social Sciences teachers' views on the integration of History and Geography in the General Education and Training phase
}

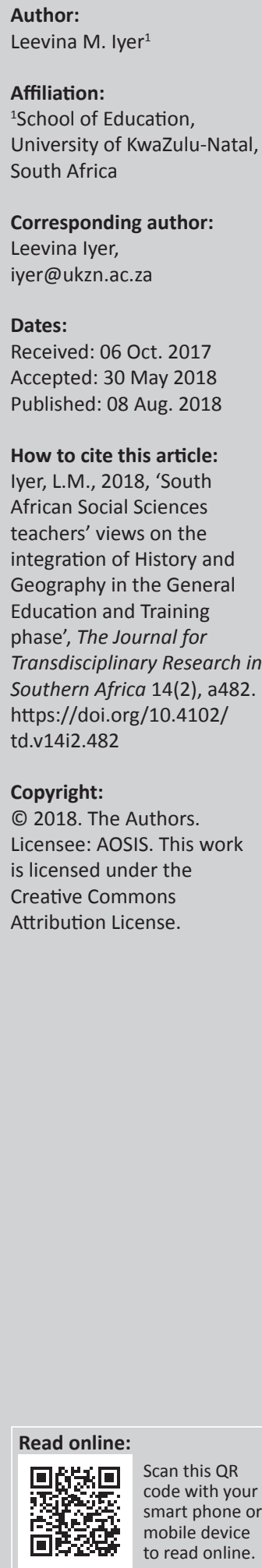

With the cessation of apartheid in 1994, social transformation was one of the key objectives of the democratic South Africa. In light of this, the South African government believed that mass education would develop a democratised mindset amongst the country's citizens. History and Geography were identified as two subjects that could promote the desired societal transformation and were thus combined into one learning area: Social Sciences. The concept underpinning this learning area was integration. The notion of integration takes different forms in the literature, and these are explored here. This study explored teachers' views on integration in relation to Social Sciences. Responses from semi-structured interviews indicated that integration in Social Sciences varied as conceptual, physical and social processes. The study results revealed that integration in Social Sciences is devoid of metanarratives, as there was a degree of discongruity in teachers' views of integration in Social Sciences. Despite this, inherent commonalities were evident in their responses in terms of disciplinary proficiency, issues of diversity and engagement in a globalised world. These were reflected in the participants' responses as being important to explore when integrating History and Geography in Social Sciences.

\section{Introduction}

This article begins with a brief overview of the South African education system during the apartheid era. This is because education under apartheid, in effect, underpinned the reasons for the move towards a democratised curriculum. During apartheid racist and separatist policies, especially within education, served to produce particular identities for its citizens depending on the role the government wanted for different groups of people to play in the society (Beets \& Le Grange 2008; Msila 2007). To produce these specific identities, different levels and types of content were driven by education policies and practices. In particular, black South African learners were constrained by an education system that assisted in developing their identity as docile, subservient labourers who would submit to the rules of segregation (Christie \& Collins 1982; Msila 2007). Black South African learners were exposed to the most rudimentary topics in the curriculum (Msila 2007). These topics lacked depth and breadth and did not advance critical thinking and higher order cognitive skills. In this way, the apartheid education system failed to develop historical and geographical consciousness in black South African learners. In contrast, white South African learners were exposed to various topics related to local and international issues (Nkondo 1979). The topics promoted active engagement and equipped learners with deep content knowledge and a wide scope of historical and geographical education.

Given the above educational and societal injustices of apartheid, the post-1994 democratic government aimed to use education as a tool to bring a sense of equality to all the country's citizens (Carrim 2001). Policy-makers believed that the integration of History and Geography would assist in achieving this equality. There were two reasons for the integration of History and Geography. Firstly, as asserted by the National Education and Training Forum (NETF) representatives, History and Geography were fundamentally viewed as being sub-fields of Human Sciences and Social Sciences (Department of Basic Education 2002). This meant that both subjects were viewed as having had content which, if integrated, had the potential to develop holistic thinking and achieve positive societal transformation. Moreover, with the increase in globalisation (Buckley \& Ghauri 2004), this content offered a new way of thinking and engaging particularly with economic growth. Secondly, in terms of political sphere, the South African government maintained that segregation between History and Geography should be replaced 
with a concept indicative of unification and collaboration (Department of Basic Education 2002). This concept was integration, a reaction against the divisions created by apartheid which manifested itself in Social Sciences. Social Sciences was thus meant to initiate change in the way people acknowledged each other. Rather than discriminate against differences, the post-1994 South African government wanted people to embrace their diversity, and knowledge of this diversity could be articulated to the masses via engagement with, for example, Social Sciences.

While the integration of subjects has been explored and advocated widely within the international context, it made an appearance in the early 1990s within the political sphere in South Africa (Bird 2001; Pawson \& Dovers 2003; WarleighLack 2006). With the advance of democracy in South Africa, there was a need to promote a democratic mindset. The Social Sciences curriculum was a way in which democratic thinking could be achieved. Considering this, integration can be regarded as a political concept (Pawson \& Dovers 2003; Seekings 2002; Wieviorka 2005). Consequently, the aim of Social Sciences was to achieve a sense of oneness amongst South Africans through the topics discussed in each of the two subjects. These topics revolved around personal experiences of people, lost voices of the oppressed, societal and environmental inequalities and exploitation, and quality of the environment and its impact on people - all of which help learners place South Africa in the context of a globalised world (Department of Basic Education 2012).

This article is primarily based on a historical study of the Social Sciences National Curriculum Statement (NCS) - the previous curriculum in South Africa. This was replaced in 2012 by the Social Sciences Curriculum and Assessment Policy Statement (CAPS). Against this background, the purpose of this study was to gain a sense of how 21st century teachers in the democratic South Africa viewed the integration of History and Geography in the General Education and Training phase. This phase includes grades $\mathrm{R}$ to nine in South African schools. Teachers are primarily responsible for achieving the integration of History and Geography in Social Sciences, therefore this study considered their views. Two research questions underpinned this study. These were, firstly, to determine how Social Sciences teachers viewed the integration of History and Geography and, secondly, to establish what topics in the Social Sciences curriculum teachers believed could promote integration of History and Geography. Essentially, this study was qualitative in nature and thus the data collection method included semi-structured interviews. What follows is engagement with literature related to integration and Social Sciences.

\section{Literature review}

Essentially, in the South African sociopolitical context of the time, the Department of Basic Education (2002:107) explained that integration consists of three perspectives: 'combining parts into a whole', 'coming into equal membership of society, specifically without regard to race or religion' and 'the ending of racial segregation'. In effect, the Department of Basic Education has explicitly communicated the political status of integration to stakeholders through the Social Sciences policy documents. These stakeholders included teachers, learners, policy-makers and government departments, amongst others. Essentially, the agenda driving curriculum policy documents, in particular the policy for Social Sciences, has served to promote social transformation. However, academic integration can occur in multiple ways, depending on the context.

The abovementioned political ideals of the Social Sciences curriculum are consistent with the term social integration (Beekhoven, De Jong \& Van Hout 2002; MłynarczukSokołowska 2017; Parker 2015). As stated by Błeszyńska (2017), social integration can improve education based on people and places. Parallels can thus be drawn with historical and geographical education. Social integration can enhance relationship between people in the community and teachers and learners. It does not only expand learners' knowledge of operating within social conventions but also exposes them to different behavioural perspectives. Societal changes are a key objective of Social Sciences, especially to promote tolerance, respect, acknowledgement, citizenship and, in essence, a sense of Ubuntu - an African framework that promotes unity and inclusion (Maposa 2017). This idea is further emphasised by Młynarczuk-Sokołowska (2017) who posits that social integration can influence an individual's identity. Learners are able to develop a sense of respect and appreciation for people from diverse backgrounds by engaging with topics in the Social Sciences curriculum. In essence, social integration assists in developing learners who can actively participate in achieving the goals of a democratic South African society.

Furthermore, transdisciplinarity can also assist in achieving integration in Social Sciences. Transdisciplinarity occurs when topics from either History or Geography are analysed by experts and non-experts to create a broad understanding of underlying concepts (Nicolescu 2010). For example, transdisciplinary collaboration could occur when teaching the Grade 7 Geography topic 'Natural resources and conservation in South Africa'. In this instance, experts such as representatives from the Wildlife and Environment Society of South Africa (WESSA), could be invited to present a guest lecture on the importance of conserving natural resources which would directly link to 'cause and consequence' as a historical concept and 'human activities' as a geographical concept.

It is evident from the above clarification of concepts that integration between History and Geography can occur through disciplinary collaborations. This suggests that, presently, integration in the 21st century Social Sciences curriculum not only refers to the thematic collaboration of History and Geography, but also refers to the pedagogical, political, socio-economic and environmental relationships between the two subjects in an integrated manner. 


\section{Methodology}

An interpretive research design was used in this study as it looks at how people perceive their worlds within particular contexts (Schwartz-Shea \& Yanow 2013). The purpose of this study was to gain a sense of how teachers view the integration of History and Geography in Social Sciences. Moreover, symbolic interactionist theory constructed the theoretical framework for this study. At the focal point of symbolic interactionist theory is the belief that there is a relationship between authenticity, self-efficacy and self-esteem, and this determines how individuals view their role in society (Reynolds \& Herman-Kinney 2003). This framework was apposite, as this study intended to answer two key research questions: to determine how Social Sciences teachers view the integration of History and Geography and to establish what topics in the Social Sciences curriculum teachers believed could promote the integration of History and Geography.

In accordance with the aforesaid objectives, this study was qualitative in nature, because it allowed for rich, thick, meaningful data to be elicited from participants who had expressed their personal experiences and views (Trochim 2006). Devlin, Hansen and Selai (2004) maintain that using a qualitative methodology for acquiring data is a valid and reliable way of obtaining first-hand data. In keeping with qualitative research, semi-structured interviews were conducted as part of data collection. This was chosen, because semi-structured interviews allowed for a great deal of insights into the Social Sciences teachers' views in relation to integration in Social Sciences. Semi-structured interviews are guided by structured questions. However, if a participant mentions something of interest, the interviewer can probe further and does not need to strictly follow the predetermined questions (Greener 2008). This assisted when participants of this study were not clear about their responses or when their answers needed clarification.

The study entailed purposive sampling, as a specific set of aspects was considered when choosing participants. Four Social Sciences teachers from different socio-economic contexts participated in the study. The teachers taught Social Sciences within the General Education and Training phase. Public schools and independently run schools were included given that the study was intended to draw on the broader system of South African schools. As the aim was to acquire in-depth data from participants, a small sample was chosen. By considering participants from different socioeconomic and educational contexts, an insight was gained into how teachers of differing characteristics viewed the integration of History and Geography into Social Sciences. To maintain the anonymity of the participants, they were referred to as Teacher A, Teacher B, Teacher C and Teacher D. Table 1 illustrates the professional biography of each participant.

The analysis of the semi-structured interviews was primarily conducted through open coding (Cohen, Manion \& Morrison 2007; Moghaddam 2006; Rapley 2007). This entailed identifying significant issues which generate emergent theories and thus included note-taking during interviews and categorising themes from the acquired data $\left(\mathrm{O}^{\prime} \mathrm{Connor}\right.$ et al. 2003). Subsequent to open coding is the process of axial coding whereby relationships were determined amongst identified themes. Then, selective coding was conducted to discover how and why inter-relationships exist between identified categories and their correlation with integration.

\section{Findings of the study}

Results from the semi-structured interviews will now be discussed. Responses of the participants clearly demonstrated a dissimilar understanding of integration in Social Sciences. The way in which they explained integration ranged from integration relating to a concept, integration as pedagogical practice, integration as social tools or integration as content, each of which was adopted by one or other teacher.

\section{Making sense of integration}

In essence, integration meant three main attributes to Teacher A. Firstly, she saw integration, in the context of Social Sciences, as the combination of History and Geography, having the status two different disciplines with their own focal point. She points out the difference between History and Geography to her learners in the first Social Sciences lesson of the year. She states, 'Geography is the relationship between man and his environment and how does it affect you ... History is peopleto-people; about interpersonal relationships.'

Subsequently, Teacher A associated integration with communication abilities of learners. For instance, she mentioned, "The way they answer they don't care about the "is" and "was." They need to speak and write properly.' She believes that integration in Social Sciences also occurs in terms of literacy skills. She is certain that such integration can help learners enhance their verbal and writing skills as well as correct the irregularity in the way they speak and write.

TABLE 1: Professional biography of the participants.

\begin{tabular}{llllc}
\hline Teacher & Age & Type of school & Teaching specialisations or majors & $\begin{array}{c}\text { No. of years teaching } \\
\text { Social Sciences }\end{array}$ \\
\hline Teacher A & 32 & Public & Arabic, English and History & 3 \\
Teacher B & 56 & Independently run & Psychology, English and Geography & History only \\
Teacher C & 35 & Independently run & HMS (Physical Science) and Geography & 5 \\
Teacher D & 48 & Public & Geography and Economics & 6 \\
\hline
\end{tabular}


In another attempt to explain integration, Teacher $\mathrm{A}$ maintained that integration can exist between Social Sciences and other learning areas, especially with English and Life Orientation. This relates to her previous understanding of integration in that English and Life Orientation are learning areas which can complement Social Sciences with regard to developing learners' reading, writing and empathic skills as well as morals and values as alluded to earlier.

In contrast to Teacher A, Teacher B was unable to provide a description of what integration meant to her. She, instead, cited an example of an integrated topic from the Social Sciences curriculum:

'When we teach the Rwandan genocide in Grade 9, the fact that the Hutus and Tutsis, for generations, lived in different little entities alongside and then the British came along and lumped them in a country called Rwanda, left them and then there was a power vacuum and a power struggle ... it was forced upon them, you know the geographical binding of the two tribes who have never lived together, who are now being bound together from separate little entities. And if it hadn't been for the interlopers who came and started moving them ... thousands of lives would have been saved, you know. So there always has to be a histo-geographical point of view.' (Teacher B, 56 years old)

Furthermore, integration, as maintained by Teacher B, can be assisted by eliciting learners' experiences. She stated that 'a lot also comes from learners - what they know, what they bring to class, you'd be surprised at how useful their input can be'.

Similarly, Teacher C used an example of the Battle of Blood River as she explained that textbooks assist Social Sciences teachers and learners with understanding integration in Social Sciences. In addition, she often referred to integration as a 'relationship':

'Well we normally do that relationship like when we're doing the war; you know the landscape, um that sort of thing. Sometimes you can ignore the relationship, but sometimes there is a strong relationship. You can bring in the Geog with the History, but you know it is sometimes difficult.' (Teacher $\mathrm{C}$, 35 years old)

Teacher $\mathrm{C}$ seemed to comprehend that History and Geography share a relationship of some sort. She also understood that integration was not always evident in Social Sciences. The fact that she stated that 'sometimes you can ignore the relationship' indicates that she chose when to engage with the integration process in her Social Sciences lessons and was not consistent in her approach to integration.

In essence, Teacher D seemed to find it difficult to explain integration when asked about what he understood by integration in Social Sciences, as he stated, 'not really sure how you're gonna answer that question'. Nevertheless, Teacher D adopted a similar response as Teachers B and C with regard to describing integration through the use of examples from the Social Sciences curriculum. He stated:
'See, if you're doing the French Revolution or Nazi Germany you can draw parallels between that and the Apartheid era. Most of the things you do there seems to be overlapping in Apartheid.' (Teacher D, 48 years old)

Teacher D appeared to be referring to the integration of topics within a specific discipline - in this instance, History.

\section{Teachers' views on the potential of topics in the Social Science curriculum to promote integration}

In essence, Teacher A had learners who enjoyed topics such as global warming. She maintained that all the prescribed topics are relevant, and History and Geography can be explored in an integrated manner irrespective of the topic being taught. Besides the relevance of knowledge content, Teachers B and A concurred that topics covered in Social Sciences should also aim to develop learners' morals and values. Teacher A stated that:

'Even if you draw from the media and religion ... that moral development goes every day in every lesson, also that intercultural, interfaith discussion like 'what do they say about global warming', you know. It helps with inter-tolerance and makes them open-minded. History and Geography go onto another level now.' (Teacher A, 32 years old)

Teacher B maintained that the French Revolution is a good example of integration and it allowed her to examine and elaborate on socio-economic and political aspects with her learners. She used the French Revolution to scaffold and integrate her learners' cognitive and interpersonal skills of Social Sciences in addition to their moral development as advocated in the Social Sciences curriculum. She stated:

'How can we, as human beings, learn from this great French Revolution and become peace-lovers and to pour the oil over the water. And so, I use the examples in the past as that we can enhance their lives in the future so that they can become thinking people. Um, we need to go beyond the three bear's story-telling stage so that they can use the concepts they've been taught for the betterment of their lives and of others.' (Teacher B, 56 years old)

A different perspective came from Teacher $C$ who felt that topics, which are more 'current', should be included in the Social Sciences curriculum so as to further promote integration. She stated that some of her learners complained that they should do current topics and that they did not find heritage appealing.

In contrast to Teachers A, B and C, Teacher D did not express much concern over the importance of topics to promote integration in Social Sciences. Instead, he took into account the availability of resources. He maintained that, 'we place more emphasis on resources and looking after the environment throughout the year, even though it is covered towards the end of the textbooks'. The topic, concerning the environment, is one that Teacher D believed can be integrated, as it is not subject to a few Social Sciences lessons only and is taught continuously throughout the year. 


\section{Discussion}

Based on the findings from data generated in this study, participants held five main views of integration in Social Sciences. These were:

- Educational: integration as a means of disciplinary collaboration between History and Geography.

- Political: emphasis on unity and togetherness as a means to address the ills of the pre-democratic South Africa.

- Social: use of communication in an integrated manner, in addition to developing a set of behaviours to conform to what is acceptable in society.

- Economic: promoting participation in a contemporary globalised world.

- Moral: emphasis on building individual character with traits of open-mindedness, tolerance and respect.

In this study, all participating Social Sciences teachers had differing views of what integration was and what it should entail. Applying the insights of literature to the data, it is evident that Teachers A and B, in particular, saw themselves as what Klein (2006) terms connection experts as they continuously attempted to take advantage of opportunities to integrate themes and topics into Social Sciences. For example, the Rwandan genocide addresses issues of racism and sociopolitical prejudice. In this instance, integration has occurred through cross-disciplinary collaboration and occurs whereby multiple perspectives from History are used to enhance the understanding of other topics including those in Geography (Davies \& Devlin 2007). In addition, Teacher B was able to put into context the complementary nature of History and Geography in Social Sciences, especially as she uses a quasi-concept histo-geographical. This is important, because the knowledge to integrate History and Geography is central to Social Sciences. To accomplish this, she used the topics in the Social Sciences curriculum to make sense of it.

Amongst all the participating Social Sciences teachers' responses, there has been some mention of assisting learners in areas other than academia. For instance, the issue of reading and writing correctly was of great concern to a participant who believed that it was only through integration that difficulties of literacy could be overcome. In effect, the concept of integration has been associated with the development of communication, literacy and morals rather than the collaboration of History and Geography. This demonstrates a clear move away from exclusively academic integration to a form of language across the curriculum approach. This approach seeks to improve communication skills of learners through content and skills of subjects, rather than having to rely solely on language subjects, and is viewed as a process rather than a product (Van Lier 2014).

Furthermore, the participating Social Sciences teachers have taken advantage of opportunities to apply integration to the South African and international communities. This correlates with Namiotko and Konaszewski (2017), who assert that community plays an integral part in attaining social integration. Teacher B, for example, made reference to the French Revolution through which she would provide disciplinary and social integration. Learners were formally provided with academic content knowledge of the French Revolution, whilst being given a chance to develop their interpersonal interactions. Moreover, this correlates with Jansen and Taylor (2003), who posit that integration of History and Geography in the South African education system can assist in achieving political stability. Integration as a social tool and political mechanism, in this case, can be seen as inextricable with specific reference to teachers attempting to achieve social transformation through the Social Sciences curriculum.

Despite the difference in views of integration, the participants shared the principal idea of drawing upon both the History and Geography disciplines. A common perspective amongst the participants is that History and Geography can be integrated especially in terms of metaphysical attributes and values, irrespective of topics being taught. Disciplines are said to go beyond their initial purpose or traditional nature and are now comparable and related to the daily lives of learners (Beekhoven et al. 2002; Lam \& Lidstone 2001). Integration, in this instance, occurred through pluridisciplinarity collaboration whereby knowledge and skills from History and Geography are drawn upon to analyse themes in the Social Sciences curriculum (Stevens et al. 2005).

Furthermore, Teacher A was clear in her response to the potential of Social Sciences topics to promote integration. She spoke about enhancing learners' integrity and moral virtue which, she believed could be achieved particularly through engagement with issues of religion and different types of media. Different knowledge systems were explored, and this extends the traditional nature of Geography and History to different physical planes. Hence, integration, in this case, means considering the range of moral and value compasses of learners. This correlates with Pawson and Dovers (2003) who believe that the aim of integration is to seek ways of complementary thinking, especially between History and Geography. Moreover, Teacher A maintained that 'History and Geography go onto another level now', referring to the fact that, according to her, both disciplines go beyond their sole purpose of being knowledge-centred to being more reflective, abstract and comparative to life outside the classroom. This indicates that integration in Social Sciences can result in the expansion of knowledge, skills and values that learners acquire. Dalke et al. (2004) and Guidera (2007) concur and state that through integration learners can apply what they learnt in Social Sciences lessons to real-life situations.

On the contrary, Teacher D considered resources to be more important than the topics being taught. To him, the resources used - irrespective of the topic - determine the success or failure of integration in the Social Sciences learning area. Therefore, integration, according to him, should occur 
spontaneously by constantly drawing on knowledge from History and Geography rather than following structured material provided in the Social Sciences curriculum. Integration occurred through multidisciplinarity which is not discipline-specific and involves drawing knowledge and skills from History and Geography (Fonn 2018; Klein 2006; Weech \& Pluzhenskata 2005).

Conversely, there was a suggestion by Teacher $C$ to include more current topics into the curriculum. This could imply a move away from traditional topics to topics that focus on contemporary issues facing learners in this age of globalisation and rapid technological advancement. The aforementioned, although advantageous to learners in that it can help them cope and adapt to the present situation of the world, could also prove to be problematic. This is because of the fact that if less emphasis is placed on traditional topics, the structure of learners' content knowledge could leave gaps in their understanding of the History or Geography discipline and the different dynamics facilitating the engagement with these disciplines in everyday life. Effectually, integration, according to Kwadrans (2017), can assist learners in developing a national identity and promote citizenship education which will help learners engage in contemporary society - both nationally and internationally. This is supported by Maposa (2017) and Młynarczuk-Sokołowska (2017), who believe that issues of Ubuntu and national identity can be enhanced through Social Sciences.

Integration was thus be viewed as a broad generic term that entailed different types of disciplinary collaborations which occurred at various levels in Social Sciences. Several meanings of integration have ranged from communication and discipline collaboration to moral and social developments.

\section{Conclusion}

This article argues that one of the fundamental structural bases of Social Sciences, which can achieve complementary thinking, is integration. Essentially, multiple voices emerged through an analysis of the data and there existed a degree of dissimilarity in participants' views of integration in Social Sciences. In addition, participants held heterogeneous views with regard to whether topics, included in the Social Sciences curriculum had the potential to promote integration. Ultemately, no metanarratives in relation to teachers' views of integration in Social Sciences are existing. This is reflective of postmodernity, as there were different views and no objective truth. Despite the fact that the participating Social Sciences teachers offered a plurality of meanings of integration, commonalities were evident in their responses. Issues of disciplinary proficiency, diversity, open-mindedness and the importance of being able to cope in a globalised world were reflected in the participants' responses as being important to explore when integrating History and Geography in Social Sciences.

This study is not without limitations. A broader perspective would come from bringing in learners' views of the integration of History and Geography rather than that of teachers. To gain sufficient depth in exploring participants' views, this study focused on four Social Sciences teachers. Future researchers could consider a larger sample and could conduct observations or focus group interviews to gain a first-hand sense of how teachers enact integration in Social Sciences lessons.

\section{Acknowledgements Competing interests}

The author declares that she has no financial or personal relationships which may have inappropriately influenced her in writing this article.

\section{References}

Beekhoven, S., De Jong, U. \& Van Hout, H., 2002, 'Explaining academic progress via combining concepts of integration theory and rational choice theory', Research in Higher Education 43(5), 577-600. https://doi.org/10.1023/A:1020166215457

Beets, P. \& Le Grange, L., 2008, 'Has geography curriculum reform in post-apartheid South Africa strengthened continuity and progression?', South African Geographical Journal 90(2), 68-79. https://doi.org/10.1080/03736245.2008.972 5315

Bird, E., 2001, 'Disciplining the interdisciplinary: Radicalism and the academic curriculum', Journal of Sociology of Education 22(4), 463-478. https://doi.org/ 10.1080/01425690120094430

Błeszyńska, K.M., 2017, 'Educating migrant students in Poland', Kultura i Edukacja 4(118), 153-167.

Buckley, P. \& Ghauri, P.N., 2004, 'Globalisation, economic geography and the strategy of multinational enterprises', Journal of International Business Studies 35(2), 8198. https://doi.org/10.1057/palgrave.jibs.8400076

Christie, P. \& Collins, C., 1982, 'Bantu education: Apartheid ideology or labour reproduction?', Comparative Education 18(1), 59-75. https://doi.org/10.1080/ 0305006820180107

Carrim, M., 2001, 'Democratic participation, decentralisation and educational reform', in Y. Sayed \& J. Jansen (eds.), Implementing education policies: The South African experience, pp. 98-109, UCT Press, Cape Town.

Cohen, L., Manian, L. \& Morrison, K., 2007, Research methods in education, 6th edn., RoutledgeFalmer, London.

Dalke, A., Grobstein, P., McCormack, E. \& Mawr, B., 2004, Theorising interdisciplinarity: The evolution of new academic and intellectual communities, viewed 09 May 2009, from http://serendip.brynmawr.edu/local/scisoc/theorizing.html

Davies, M. \& Devlin, M.T., 2007, Interdisciplinary higher education: Implications for teaching and learning, Centre for the Study of Higher Education, Melbourne.

Department of Basic Education, 2002, Revised national curriculum statement grades R-9 (schools) for social sciences, Government Printers, Pretoria.

Department of Basic Education, 2012, Social sciences CAPS curriculum and assessment policy Statement for social sciences, Government Printers, Pretoria.

Devlin, N., Hansen, P. \& Selai, C., 2004, 'Understanding health state valuations: A qualitative analysis of respondents' comments', Quality of Life Research 13(7) 1265-1277. https://doi.org/10.1023/B:QURE.0000037495.00959.9b

Fonn, S., 2018, 'Want to solve complex health issues? Train scholars to think across disciplines', The Conversation, viewed 06 March 2018, from https://theconversation. $\mathrm{com} /$ want-to-solve-complex-health-issues-train-scholars-to-think-acrossdisciplines-92188

Greener, S., 2008, Business research methods, viewed 12 April 2018, from https:// books.google.co.za/books?hl=en\&lr=\&id=mR2sPdKOBIUC\&oi=fnd\&pg=PA9\&dq= Business+research+methods $\% 2$ Bgreener\&ots $=11 v c 8 g B 6 n c \& s i g=x S E g c H A u B a E d o$ hLOFINSWrbrOTk\#v=onepage \&q=Business $\% 20$ research $\% 20$ methods $\%$ 2Bgreener\&f=false

Guidera, G., 2007, 'Integrated social studies - It's the concept', Lutheran Education Journal 141(1), 41-51.

Jansen, J. \& Taylor, N., 2003, 'Educational change in South Africa 1994-2003: Case studies in large-scale education reform', Country Studies Education Reform and Management Publication Series 2(1), 1-51.

Klein, J., 2006, 'A platform for shared discourse of interdisciplinary education', Journal of Social Science Education 5(2), 10-18.

Kwadrans, L., 2017, 'Roma identity, integration and education. Comparative research', Kultura i Edukacja 4(118), 60-73.

Lam, C. \& Lidstone, J., 2001, 'The implementation of a new integrated social science syllabus: Case studies from Brisbane secondary schools', Education Journal 29(2), 1-17.

Maposa, M.T., 2017, 'Ubuntu as a theoretical framework for teaching Social Sciences', in J. Wassermann (ed.), Teaching social sciences: Intermediate and senior phases, pp. 19-43, Oxford University Press Southern Africa, Cape Town. 
Młynarczuk-Sokołowska, A., 2017, 'Education of Foreign children in Poland. Methodical contexts', Kultura i Edukacja 4(118), 168-181.

Moghaddam, A., 2006, 'Coding issues in grounded theory', Issues in Educational Research, 16, viewed 28 August 2010, from http://www.iier.org.au/iier16/ moghaddam.html

Msila, V., 2007, 'From apartheid education to the Revised National Curriculum Statement: Pedagogy for identity formation and nation building in South Africa', Nordic Journal of African Studies 16(2), 146-160.

Namiotko, U. \& Konaszewski, K., 2017, 'From conflict to reconciliation. Creating the national identity on the polish-Lithuanian borderland', Kultura i Edukacja 4(118), 74-93.

Nkondo, C., 1979, 'Comparison of the syllabus of the Bantu education department with that of the Transvaal education department and other related matters', Reality 11(4), 17-19.

Nicolescu, B., 2010, 'Methodology of transdisciplinarity', World Futures 70(3-4), 186-199.

O'Connor, G., Rice, M.P., Peters, L. \& Veryzer, RW., 2003, 'Managing interdisciplinary, longitudinal research teams: Extending grounded theory-building methodologies', Organization Science 14(4), 353-373. https://doi.org/10.1287/orsc.14.4.353.17485

Parker, W.C., 2015, Social studies today: Research and practice, Routledge, New York viewed 15 March 2018, from https://books.google.co.za/books?id=8YkGCAAAQBA \&printsec=frontcover\&source=gbs_ge_summary_ $r \&$ cad $=0 \# v=$ onepage\& $q \&=$ false

Pawson, E. \& Dovers, S., 2003, 'Environmental history and the challenges of interdisciplinarity: An Antipodean perspective', Environment and History 9(1), 1-23. https://doi.org/10.3197/096734003129342773
Rapley, T., 2007, Doing conversation, discourse and document analysis, Sage, London. Reynolds, L.T. \& Herman-Kinney, N.J., 2003, Handbook of symbolic interactionism, Rowman AltaMira Press, Oxford.

Schwartz-Shea, P. \& Yanow, D., 2013, Interpretive research design: Concepts and processes, Routledge, New York.

Seekings, J., 2001, 'The uneven development of quantitative social science in South Africa', Social Dynamics 27(1), 1-36.

Stevens, R., Wineburg, S., Herrenkohl, L. \& Bell, P., 2005, 'The comparative understanding of school subjects: Past, present and future', Review of Educational Research 75(2), 125-157. https://doi.org/10.3102/00346543075002125

Trochim, W., 2006, Qualitative methods, viewed 05 November 2010, from http:// www.socialresearchmethods.net/kb/qualmeth.php

Van Lier, L., 2014, Interaction in the language curriculum: Awareness, autonomy and authenticity, Routledge, New York.

Warleigh-Lack, A., 2006, 'Towards a conceptual framework for regionalisation: Bridging "new regionalism" and "integration theory", Review of Internationa Political Economy 13(5), 750-771. https://doi.org/10.1080/09692290600950639

Weech, T. \& Pluzhenskaia, M., 2005, 'LIS education and multidisciplinarity: An exploratory study', Journal of Education for Library and Information Science 46(2) 154-164.

Wieviorka, M., 2005, 'From Marx and Braudel to Wallerstein', Contemporary Sociology 34(1), 1-7. https://doi.org/10.1177/009430610503400102 